\title{
Educational Policy Implementation: Adaptation Differences among Secondary School Teachers in Malaysia
}

\section{Nik Abd Rahman Nik Yaacob Yahya Don ${ }^{2}$ Mohd Faiz Mohd Yaakob ${ }^{3}$}

${ }_{1,2, s}^{t}$ School of Education and Modern Languages, Universiti Utara Malaysia, Malaysia.

Email:mohdfaizmohdyaakob@gmail.com

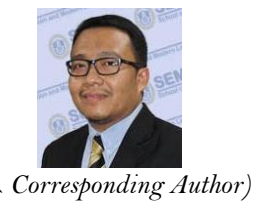

( Corresponding Author)

\section{Abstract}

Malaysia has undergone various transformations in education since its independence in 1957 . The work environment plays an important role in teacher adaptation, so this study aimed to identify the differences in the level of teacher adaptation to change in Malaysian education policy in National Secondary Schools (SMK) and Government Funded Religious Schools (SABK). This quantitative research which used a simple random sampling technique was conducted at the randomly selected National Secondary Schools (SMK) and the Government Funded Religious Schools in the state of Kelantan. A total of 300 samples were involved in answering the distributed questionnaire which was an adaptation of Samale (2016) built on the Measure of Adaptive Performance (MAP) instrument by Lillard et al. (2012) and the Individual Adaptability Theory (I-ADAPT) instrument by Ployhart and Bliese (2006). The findings showed that the level of teachers' adaptation was high and there was no difference in the level of adaptation between SMK and SABK teachers. It is hoped that the results of this study can be used as a reference specifically to school administrators and the education ministry towards improving teachers' adaptation to a very high level. This is important because teachers are the leading implementers of education policy in schools and individuals who can fulfil the aspiration of the Ministry of Education to place education in Malaysia on par with the world-class system.

Keywords: Educational management, Teacher education, Policy implementation, Government funded religious schools (SABK), Teachers' adaptation, Education policy.

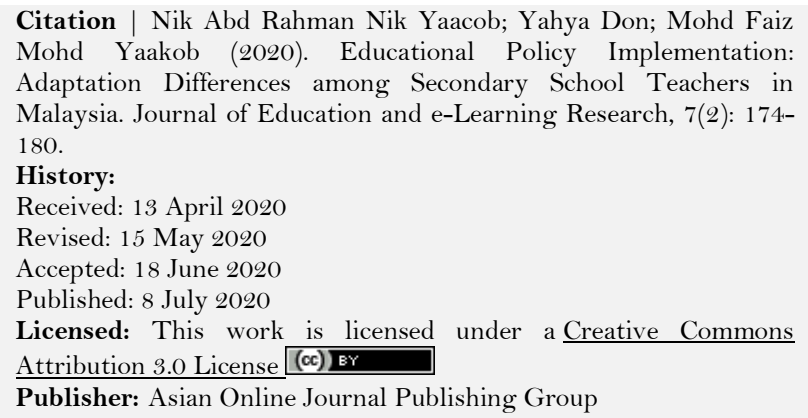

Citation | Nik Abd Rahman Nik Yaacob; Yahya Don; Mohd Faiz Mohd Yaakob (2020). Educational Policy Implementation: Adaptation Differences among Secondary School Teachers in Malaysia. Journal of Education and e-Learning Research, 7(2): 174180.

History:

Received: 13 April 2020

Revised: 15 May 2020

Accepted: 18 June 2020

Published: 8 July 2020

Licensed: This work is licensed under a Creative Commons

Attribution 3.0 License $(\mathrm{cc}) \boldsymbol{F}_{\mathbf{E}}$

Publisher: Asian Online Journal Publishing Group

Acknowledgement: All authors contributed to the conception and design of the study.

Funding: This study received no specific financial support

Competing Interests: The authors declare that they have no conflict of interests.

Transparency: The authors confirm that the manuscript is an honest, accurate, and transparent account of the study was reported; that no vital features of the study have been omitted; and that any discrepancies from the features of the study have been omitted;
study as planned have been explained.

study as planned have been explained.
Ethical: This study follows all ethical practices during writing.

\section{Contents}

1. Introduction

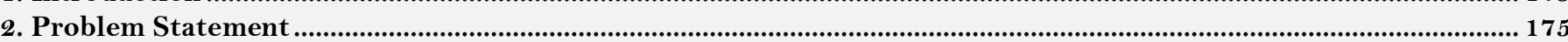

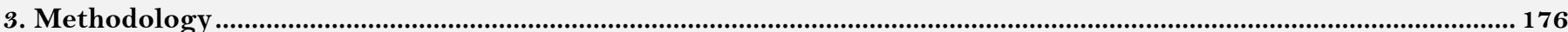

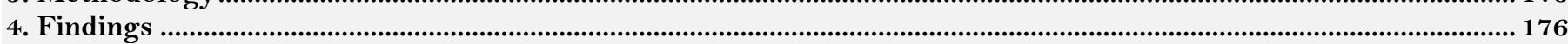

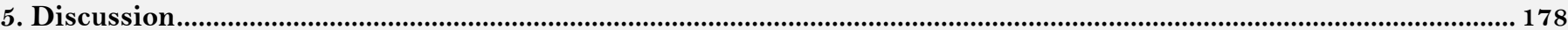

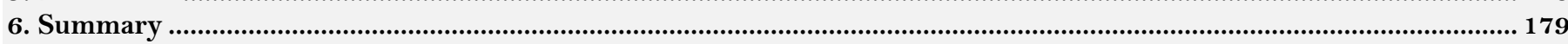

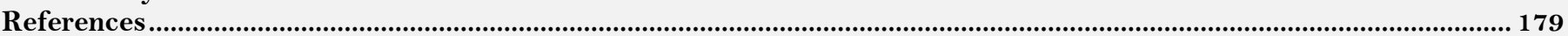




\section{Contribution of this paper to the literature}

This study contributes to existing literature by identifying the differences in the level of teacher adaptation to change in Malaysian education policy in National Secondary Schools (SMK) and Government Funded Religious Schools (SABK).

\section{Introduction}

Education is seen as a very important vessel in shaping citizens and the nation. Education is also a vehicle for the development of a country. Thus, the transformation of education is a necessity for a country to continuously improve its education system in keeping up with the fast-moving global environment. Transformation in education is a national action plan to fulfil the demands of the National Education Philosophy.

Malaysia has undergone various transformations in education since its independence in 1957. In 1983, the New Primary Curriculum (KBSR) was introduced along with the Secondary Integrated Curriculum (KBSM) in 1989. Later in 2003, revisions of the KBSR and KBSM were made to further improve the existing curriculum. The national education transformation did not stop there, for in 2010 the Standard Curriculum was introduced, namely the National Preschool Standard-Based Curriculum (KSPK), the Standard Curriculum for Primary Students (KSSR) and the Standard Curriculum for Secondary Students (KSSM). Vocational education institutions are also undergoing a transformation in education so that the status of the country as a developed nation can be realized in the future. In line with the current educational reforms, new education policies are being introduced such as Upholding the Malay Language and Strengthening Command of English (MBMMBI), One Student One Sports (1M1S), School-Based Assessment (PBS). Various programs have been developed at the ministry level to support the implementation of the education policy. The transformation in education is to improve and enhance the capacity of the country's education system to meet current and future challenges. The development of the education world is now entering the era of technological innovation that demands the adaptation of the education system to meet the demands of the job market (Malaysia Education Ministry, 2001).

In addition, the Ministry of Education Malaysia also launched the Malaysian Education Development Plan (PPPM) 2013-2025 in September 2013 which aimed at boosting the performance of the education system in comparison with other developed countries through the transformation of national education. There are three main waves in this plan: the first wave for phase 2013-2015, the second wave for phase 2016-2020 and the third wave for phase 2021-2025. The plan also saw eleven shifts demanding change in the educational system in Malaysia. All these changes are geared towards quality education in realizing the goal of becoming a developed nation in the future.

Changes in policy make the tradition of teachers' careers shift towards a more complex and challenging direction where teachers need to adapt quickly to the changes that are made to stay relevant to the current situation. The ability and willingness of teachers to implement change can be assessed through the way the teachers adapt. Individuals with high levels of adaptation are those who can adapt to changes in the work system or job role. According to Pearlman and Barney (2000) adaptation is an individual quality that is essential in dealing with ambiguity, dealing with uncertainty and stress and working beyond the norms. Therefore, teachers need to be creative and innovative in dealing with unforeseen circumstances in the education system. This is in line with Pulakos, Arad, Donovan, and Plamondon (2000) who interpret creative problem solving as having innovative ideas, adopting new approaches, thinking outside the box and integrating information well.

\section{Problem Statement}

Changes in the education policy of the country are seen to have a positive impact on the sustainability of the education system, but sometimes it can be difficult for teachers to adapt to these changes. The difficulties and complexities of change cause teachers to encounter the dilemma between the common practices and new ideas. The ideas of evolution and communication, the implementation of new programs and policies and the explosion in decision-making related to education, government and economics are difficult to be anticipated, in which the criteria are found in complex disciplines (Trombly, 2014).

In order to ensure that educational policy changes are implemented successfully, all educational organizations throughout Malaysia including school institutions should play their part effectively. This is because the education system in Malaysia is centralized, where the education policy and goals set by the Ministry of Education must be implemented at all levels of schools in the country including the National Secondary School (SMK) and the Government Funded Religious School (SABK). In schools, the individuals responsible for ensuring the successful implementation of these policies and goals are the teachers. Changes that occur especially in the education system involve education policies that require teachers to make current changes in line with these transformations. The transformation of education has made teachers' working situation more challenging in terms of quality or situation (Poole, 2008) and the burden of teachers' work has increased significantly since the 1980s (Price Water House Coopers, 2001; Schembari, 1994). The issue is how well the teachers can adapt to the changes while at the same time display excellent work performance.

In addition, the work environment is constantly changing, especially when new approaches, programs and policies are introduced by the education ministry. Change is a dynamic and ongoing process that occurs for individuals and organizations in response to the current and future needs. Most teachers are faced with the demands of more challenging school assignments. This requires the teachers to be always ready to perform tasks that are sometimes beyond the normal routine of the teacher. Some teachers may be able to deal with it. Nevertheless, from the researcher's point of view there are also educators who face challenges and complexities in their careers but are unable to adapt to the new changes.

Two categories of schools were selected in this study: SMK and SABK. The two categories of schools were viewed from different angles. Significant differences can be seen in terms of infrastructure, organizational structure, number of teachers and students, and the learning environment itself. SMK is a government-run public school in Malaysia that can be said to be better in many ways than SABK. SABK is a school which has undergone change from the People Religious Schools (SAR) and was registered under the Ministry of Education on August 12, 2008. 
The SAR transition to SABK aimed to empower religious schools to stay afloat in all aspects and in line with the mainstream education. Therefore, both categories of schools were selected to determine whether there were differences in the level of adaptation to Malaysian education policy change.

In addition, teachers are also seen as having diverse backgrounds of skills, knowledge, past experiences and psychology. Differences among teachers are also factors that impede or influence the implementation of educational change (Fullan, 1993). The findings from the results of previous researches have revealed several factors that have been found to be significant in influencing teacher readiness and adaptation. Among them are teacher experience and skills factors (Guskey, 1988) teacher attitude (Ghaith \& Yaghi, 1997) teacher interest and compatibility factors for change itself (Mohlman, Coladarci, \& Gage, 1982) degree of difficulty in implementing change (Ghaith \& Yaghi, 1997) and the factors of belonging and passion (Kennedy, 1988). Campbell (1994)and Motowildo, Borman, and Schmit (1997) also acknowledged that today's work requires a level of flexibility and adaptability.

Although there were many studies conducted by researchers on the concept of adaptation, most researchers agreed that the concept of adaptation has the customization or flexibility in several aspects, for example in organizational structure, information technology, or individual behaviour. Customization has become the basis of every job as much of the stability and predictions of the work environment that existed in the past have been eliminated (Haeckel, 1999; Ilgen \& Pulakos, 1999). Unlike past work environments where many things can be planned in advance, today's workers must have the knowledge, skills, and ability to respond quickly to meet immediate demands (Haeckel, 1999; Ilgen \& Pulakos, 1999).

This article is intended to discuss the differences in the level of teacher adaptation to changes in education policy in Malaysia among SMK and SABK teachers in the state of Kelantan, Malaysia. It is hoped that this article serves as a turning point for a better change in the way teachers adapt to the Malaysian education policy as teachers are the key asset that move the success in education.

\section{Methodology}

This research was a quantitative research using simple random sampling technique. The study population was 1031 teachers in Kelantan. A total of 300 teachers were involved as samples from seven different schools, four SMKs and three SABKs. The formula for setting the sample size was based on Chua (2011). In this study, a questionnaire which consisted of two sections, $\mathrm{A}$ and $\mathrm{B}$, was used to obtain the findings. Part $\mathrm{A}$ dealt with the demographics of the study sample while Part B dealt with teachers' adaptation to education policy in Malaysia. The questionnaire used in Part B was an adaptation of the instrument developed by Samale (2016) based on the Measure of Adaptive Performance (MAP) instrument by Lillard et al. (2012) and the Individual Adaptability Theory (I-ADAPT) instrument by Ployhart and Bliese (2006). The instrument contained 25 items with five different dimensions: (1) Active Learning, (2) Creative Application, (3) Emotional Management, (4) Situational Adaptation and (5) Opinion Flexibility. This instrument contained a 5-point Likert scale of 1 for 'strongly agree' to 5 for 'strongly disagree'. The reliability level of the instrument was determined by identifying the Alpha (Cronbach Alpha value) of $\alpha=0.87$. The data from the study were analysed using the Statistical Package for Social Sciences (SPSS) version 21.

\section{Findings}

Descriptive analysis of the demographic distribution showed that the number of SMK teachers involved was $220(73.3 \%)$, while the number of SABK teachers was $80(26.7 \%)$. The total sample was 300 . The study sample consisted of $126(42 \%)$ male teachers and $174(58 \%)$ female teachers. Most of the study samples, $127(42.3 \%)$ were in the 41-50 year old age group. Table 1 shows the demographic distribution of the study sample.

Table-1. Demographic distribution of study sample.

\begin{tabular}{c|c|c|c}
\hline Variables & Schools & Frequency & Percentage (\%) \\
\hline School & SMK & 220 & 73.3 \\
& SABK & 80 & 26.7 \\
\hline Gender & Male & 126 & 42 \\
& Female & 174 & 58 \\
\hline Age & <30 years & 27 & 9.0 \\
& 31-40 years & 75 & 25.0 \\
& 41-50 years & 127 & 42.3 \\
& >50 years & 71 & 23.7 \\
\hline
\end{tabular}

Table 2 below shows the mean of each item to determine the level of teachers' adaptation in education policy in Malaysia.

Based on Table 2, the overall mean score for all items was 3.79. This showed that the average level of overall teacher adaptation was high. Out of the 25 items, there were 21 items categorized as high. There were three items at the moderate level that was item $4(\mathrm{M}=2.87)$, item $21(\mathrm{M}=2.95)$ and item $23(\mathrm{M}=2.91)$ and one item at the lower level which was item $22(\mathrm{M}=2.65)$. The mean score for item 1 was the highest at 4.21. This exhibited that teachers were aware of the changes taking place in the education system. The mean score for item 22 was lowest at 2.65. This exposed that teachers were confused when there were too many educational policies needed to be met. Overall, even though many items showed high mean scores, they were still not able to achieve very high mean scores. 
Table-2. Overall mean score for each item

\begin{tabular}{|c|c|c|c|}
\hline Dimension & No & Items & Mean \\
\hline \multirow[t]{5}{*}{ Active Learning } & 1 & I know the changes that are happening in the education system & 4.21 \\
\hline & 7 & I am passionate about learning new technologies & 3.97 \\
\hline & 8 & I am actively involved in training for change & 3.80 \\
\hline & 9 & I make sure my knowledge is up to date & 4.06 \\
\hline & 24 & I am constantly learning to improve my professional skills & 4.04 \\
\hline \multirow[t]{5}{*}{ Situational Adaptation } & 18 & I acted as directed by the ministry & 4.16 \\
\hline & 20 & I can overcome the uncertainty at school & 3.96 \\
\hline & 21 & I am more comfortable teaching using traditional methods & 2.95 \\
\hline & 22 & I am confused when there are too many policy requirements to fulfil & 2.65 \\
\hline & 23 & The new programs introduced worry me & 2.91 \\
\hline \multirow[t]{5}{*}{ Emotional Management } & 3 & I can control my emotions for unexpected police changes & 3.93 \\
\hline & 4 & I am more emotional about the stressful news & 2.87 \\
\hline & 5 & I am calm in facing the challenging workload & 3.85 \\
\hline & 6 & I have the resilience in stressful times & 3.84 \\
\hline & 15 & I can control my negative emotions & 3.99 \\
\hline \multirow[t]{5}{*}{ Creative Application } & 10 & I can generate new ideas in the current situation & 3.87 \\
\hline & 11 & I integrate information to solve problems creatively & 3.89 \\
\hline & 12 & I think creatively for a more effective change approach & 3.95 \\
\hline & 13 & I innovate when there are not enough resources & 3.77 \\
\hline & 14 & I use existing resources creatively & 3.90 \\
\hline \multirow[t]{5}{*}{ Opinion Flexibility } & 2 & I am open towards the education policy & 4.08 \\
\hline & 16 & I know about the benefits of changing education policies & 3.97 \\
\hline & 17 & I change my behaviour according to the current situation & 4.01 \\
\hline & 19 & I consider other people's opinions & 4.07 \\
\hline & 25 & I adjust my behaviour to get along with others & 4.10 \\
\hline
\end{tabular}

Source:: Modification Measure of Adaptive Performance (MAP) by Lillard et al. (2012) and Individual Adaptability Theory (I-ADAPT) instrument by Ployhart and Bliese (2006).

Table 3 shows the mean scores and standard deviations according to the teacher adaptation dimensions.

Table-3. Mean scores and standard deviations according to teachers' adaptation dimensions.

\begin{tabular}{|c|c|c|}
\hline Dimensions & Mean & Standard Deviations \\
\hline Active Learning & 4.02 & .43 \\
\hline Situational Adaptation & 3.33 & .54 \\
\hline Emotional Management & 3.70 & .43 \\
\hline Creative Application & 3.88 & .44 \\
\hline Opinion Flexibility & 4.05 & .43 \\
\hline
\end{tabular}

Source: Modification Measure of Adaptive Performance (MAP) by Lillard et al. (2012) and Individual Adaptability Theory (I-ADAPT) instrument by Ployhart and Bliese (2006).

Based on Table 3, it was found that there were four dimensions at the highest level namely Active Learning, Emotional Management, Creative Application and Opinion Flexibility. However, there was one dimension that was at the moderate level which was Situational Adaptation. Opinion Flexibility Dimension showed the highest mean value $(\mathrm{M}=4.05, \mathrm{SP}=0.43)$. The second highest dimension was the Active Learning dimension $(\mathrm{M}=4.02, \mathrm{SP}=$ 0.43), followed by the Creative Application dimension $(\mathrm{M}=3.88, \mathrm{SP}=0.44)$ and subsequently the Emotional Management dimension $(\mathrm{M}=3.70, \mathrm{SP}=0.43)$. The Situational Adaptation dimension disclosed the lowest mean score with a value of 3.33 and a standard deviation of 0.54 . This showed that the level of adaptation of the teacher to the unpredictable and unforeseen circumstances of the school was at a moderate level.

Table 4 below shows the differences in mean scores and standard deviations for SMK and SABK based on dimensions.

Table-4. Differences in mean scores and standard deviations for SMK and SABK based on dimensions.

\begin{tabular}{l|c|c|c}
\hline Dimensions & School & Mean & Standard Deviation \\
\hline \multirow{2}{*}{ Active Learning } & SMK & 4.03 & .43 \\
\hline \multirow{2}{*}{ Situational Adaptation } & SABK & 3.98 & .42 \\
\cline { 2 - 4 } & SMK & 3.30 & .55 \\
\cline { 2 - 4 } Emotional Management & SABK & 3.39 & .43 \\
\cline { 2 - 4 } & SMK & 3.70 & .42 \\
\hline \multirow{2}{*}{ Creative Application } & SABK & 3.68 & .45 \\
\hline \multirow{2}{*}{ Opinion Flexibility } & SMK & 3.91 & .41 \\
\cline { 2 - 4 } & SABK & 4.80 & .43 \\
\cline { 2 - 4 }
\end{tabular}

Source: Modification Measure of Adaptive Performance (MAP) by Lillard et al. (2012) and Individual Adaptability Theory (I-ADAPT) instrument by Ployhart and Bliese (2006).

Based on Table 4 above, both categories of schools showed the same level of adaptation in the five dimensions. There were four dimensions at the top of both school categories: Active Learning, Emotional Management, Creative Application and Opinion Flexibility, while one dimension was at the moderate level that was the Situational Adaptation dimension. Although there were similarities in level for each dimension for SMK and SABK, there was still a notable difference in mean scores for SMK and SABK for all dimensions. The mean SMK mean score for four dimensions was higher than SABK which was Active Learning $(\mathrm{M}=4.03, \mathrm{SP}=0.43)$ compared to 
SABK mean score $(\mathrm{M}=3.98, \mathrm{SP}=0.42)$, The Emotional Management $(\mathrm{M}=3.70, \mathrm{SP}=0.43)$ compared to SABK $(\mathrm{M}=3.68, \mathrm{SP}=0.42)$, Creative Application $(\mathrm{M}=3.91, \mathrm{SP}=0.45)$ compared to $\mathrm{SABK}(\mathrm{M}=3.80, \mathrm{SP}=0.41)$ and Opinion Flexibility $(\mathrm{M}=4.07, \mathrm{SP}=0.43)$ compared to $\mathrm{SABK}(\mathrm{M}=4.00, \mathrm{SP}=0.43)$. However, the SABK mean score for the Situational Adaptation dimension was higher $(\mathrm{M}=3.39, \mathrm{SP}=0.48)$ than $\mathrm{SMK}(\mathrm{M}=3.30, \mathrm{SP}=0.55)$. The mean comparison of adaptation dimension showed that SMK teachers were more adaptive than SABK teachers.

Table 5 shows the overall differences in mean scores and standard deviations for SMK and SABK.

Table-5. Overall differences in mean scores and standard deviations for SMK and SABK.

\begin{tabular}{c|c|c}
\hline School & Mean & Standard Deviation \\
\hline SMK & 3.80 & .36 \\
\hline SABK & 3.77 & .32 \\
\hline
\end{tabular}

Based on Table 5, the mean score for SMK $(\mathrm{M}=3.80, \mathrm{SP}=0.36)$ was higher than $\mathrm{SABK}(\mathrm{M}=3.77, \mathrm{SP}=$ 0.32). Overall SMK teachers have the advantage in the adaptation aspect compared to the SABK teachers with slight mean difference and not significant difference. Both the categories of SMK and SABK schools respectively showed a high degree of adaptation to the changes in education policy in Malaysia.

\section{Discussion}

Based on the findings, the level of adaptation of SMK and SABK teachers in Pasir Puteh, Kelantan was high. There were four out of five dimensions of high teacher adaptation namely Active Learning, Creative Application, Emotional Management and Opinion Flexibility. The Dimension of Situational Adaptation was also at a moderate level.

The high level of Active Learning dimension showed that teachers were able to actively engage in learning by considering the changes that occurred in the education system. Teachers were also seen as passionate in learning new technologies and striving to improve their career by actively participating in the preparation for educational policy change. Active learning among teachers needs to be cultivated as it is a very important element in improving teacher adaptation. Someone who can easily adapt to change needs to have the necessary knowledge and skills to make the changes they want to make. According to King, Burke, and Pemberton (2005) skills need to be constantly updated to succeed in current work situations and formal learning is one way to do it. Previous studies have shown that formal learning and experience have a great impact on individual adaptation (Blanchard, 1981). Therefore, both the school administrators and the education ministry need to provide teachers with sufficient knowledge and skills such as courses that are appropriate to the educational policy changes they want to make. Learning that takes place contributes to the individual's cognitive development, the ability to adapt to changing circumstances; and contributes to the individual's personal adaptation (O'Connell, McNeely, \& Hall, 2008).

According to the findings, the Active Learning dimension did not show any significant difference between SMK and SABK schools. This is due to the culture of teacher education being the same as the national education system is centralized. The courses and the information provided are also the same regardless of SMK and SABK. In addition, self-learning can also be achieved through the growing use of smart phones among Malaysians today. Smart phones are sophisticated, dynamic and portable tools that allow users to access information regardless of the time and location. (Al-Barashdi, Buoazza, \& Jabur, 2015; Alfawareh \& Jusoh, 2014). While smart phones can be used to maximize active learning, teachers are yet to reach a very high level of active learning. It has also been explained by Alfawareh and Jusoh (2014) that although smart phones have a lot of potential for optimum use for learning, their use for this purpose is still low (Alfawareh \& Jusoh, 2014).

The high level of Creative Application for both categories of schools explained that teachers were able to think creatively in ensuring that educational policy changes were implemented more effectively. Although there may be lack of resources in the SABK schools, teachers were innovative and used existing resources creatively so that the programs proposed by the ministry to support the implementation of education policies could be implemented successfully. This in turn demonstrated the high commitment of teachers in implementing the policies entrusted by the ministry regardless of SMK or SABK. This finding is in line with the study conducted by Mohamad, Siti, Suhaila, and Hasliza (2016) where the commitment of SABK teachers in Kelantan was high and it was able to compete with other mainstream schools.

The Emotional Management dimension also showed high mean scores. This showed that teachers could handle emotions well. Teachers were able to control emotions towards policy changes and were able to control negative emotions well. The teachers were also professional and did not show excessive emotion towards stressful news. Although the task load may seem more challenging, the teachers were able to deal with it calmly. According to Mogire (2017) emotional intelligence is a key aspect of adapting. This is because people who are emotionally competent can effectively manage their emotional responses and handle their interactions with others well. Their ability to choose emotional signals and responded appropriately to changes that occurred could reduce problems. This dimension was not significantly different between the school categories. This was possible because most of the samples were Malays and Muslims.

The Opinion Flexibility dimension also contributed to the high mean score. This finding showed that the teachers were flexible and open-minded about new policy introduced or changes in the existing policies. Although there may be differences in their own opinions, teachers could still consider others' opinions or change of policies. Teachers were able to implement education policies in accordance with the requirements of the ministry. If teachers are not open to accepting the views of others or the policies formulated by the ministry, then adaptation to these changes will be more difficult. This is parallel with the findings of a study conducted on psychiatric officers by Riziandy and Fatimahwati (2013) which showed that openness and consent factors contributed to high adaptive work performance. Individuals with a high degree of openness will be more open to change, while aspects of consent will make it easier for individuals to respond to any change in the environment. The two categories of schools, SMK and SABK showed very low mean scores on the opinion flexibility dimension. This was because 
Opinion Flexibility was dependent on the individual teacher and not influenced by the type of school where they taught. Being open minded means that the individual is willing to listen to other ideas and opinions and consider the possibility that his or her own opinion is wrong or may change his or her own perspective. This can be an important quality in the workplace regardless of school category.

The findings showed that the Situational Adaptation dimension should be given careful attention as it was still at a moderate level for both the SMK and SABK schools. The findings showed that teachers needed to get clear information about a program or policy introduced in order to take more effective action. The level of Situational Adaptation was unsatisfactory when there was a drastic change that needed to be made and beyond the expectations of the teacher. Teachers needed longer time to adjust their plans, goals, actions or priorities to address changing situations. According to Nobile and McCormick (2005) the drastic changes will contribute to the pressure on teachers' work. Because of the changing nature of the education system, it has been difficult for some teachers to adapt to the changes that lead to pressure in doing their work. The pressures were likely to affect teachers' emotional, psychological and physical well-being. Therefore, the ministry is proposed to extend the policy change for teachers to be more prepared and able to plan for change.

The findings also showed that there was no significant difference in the level of adaptation of teachers to Malaysian education policy in SMK and SABK. Overall, the findings showed that the level of adaptation of SMK and SABK teachers in Pasir Puteh district in Kelantan was still not satisfying because they have not reached a very high level. This is a challenge especially for school administrators and the education ministry in devising a method to increase the adaptation level to the highest. The level of teacher adaptation needs to be improved as it is an important element in facing rapid educational policy change and teachers are the key driver in ensuring that the implementation of education policies is done more efficiently. This is in line with a study by Collie and Martin (2016) which stated that adaptability is very relevant and important to teachers because a teacher's job involves responding to ongoing change management. One of the examples provided in the study was that teachers are constantly engaged in professional learning and are expected to integrate new knowledge into their teaching practices. In addition, curriculum changes or policies may require higher adaptation from teachers.

\section{Summary}

The findings showed that the level of adaptation of SMK and SABK teachers in Pasir Puteh, Kelantan was high. There was no significant difference between the level of adaptation between SMK and SABK teachers. Although SABK has experienced SAR transition to SABK, the school still showed positive signs to compete with SMK. Teachers with high levels of adaptation are an important asset to the school and the Ministry of Education as they are key drivers in implementing education policy in Malaysia and the determinants of excellence in education. This article is hoped to assist school administrators and the ministry in helping teachers improve their level of adaptation in the future.

\section{References}

Al-Barashdi, H. S., Buoazza, A., \& Jabur, N. H. (2015). Smarttphone addiction among university undergraduates: A literature review. Journal of Scientific Research $\mathcal{E}^{2}$ Reports, 4(3), 2 10-225.Available at: https://doi.org/10.9734/jsrr/2015/12245.

Alfawareh, H. M., \& Jusoh, S. (2014). Smartphones usage among university students: Najran University case. International Journal of Academic Research, 6(2), 32 1-326.Available at: https://doi.org/10.7813/2075-4124.2014/6-2/b.48.

Blanchard, D. A. (1981). Seminary effects on professional role orientations. Review of Religious Research, 22(4), 346-361.Available at: https://doi.org/10.2307/3509767.

Campbell, J. P. (1994). Alternative models of job performance and their implication for selection and classification. In Rumsey M.G., Walker C.B. Eீ Harris J.H. (eds). Personnel selection and classification. Hillsdale, NJ: Lawrence Erlbaum Associates Inc.

Chua, Y. P. (2011). Research methods and statistics. Book 1. Research methods (2nd ed.). Kuala Lumpur: Mc Graw Hill.

Collie, R. J., \& Martin, A. J. (2016). Adaptability: An important capacity for effective teachers. Educational Practice and Theory, 38(1), 2739.Available at: https://doi.org/10.7459/ept/38.1.03.

Fullan, M. (1993). Change forces: Probing the depths of educational reform. London, UK: Falmer Press.

Ghaith, G., \& Yaghi, H. (1997). Relationships among experience, teacher efficacy, and attitudes toward the implementation of instructional innovation. Teaching and Teacher Education, 13(4), 451-458.Available at: https://doi.org/10.1016/s0742-051x(96)00045-5.

Guskey, T. R. (1988). Teacher efficacy, self-concept, and attitudes toward the implementation of instructional innovation. Teaching and Teacher Education, 4(1), 63-69.Available at: https://doi.org/10.1016/0742-051x(88)90025-x.

Haeckel, S. (1999). Adaptive enterprise: Creating and leading sense-and-respond organizations. Boston: Harvard Business School Press.

Ilgen, D. R., \& Pulakos, E. D. (1999). The changing nature of performance: Implications for staffing, motivation, and development. San Francisco: Jossey-Bass Publishers.

Kennedy, C. (1988). Evaluation of the management of change in ELT projects. Applied Linguistics, 9(4), 329-342.Available at: https://doi.org/10.1093/applin/9.4.329.

King, Z., Burke, S., \& Pemberton, J. (2005). The 'bounded'career: An empirical study of human capital, career mobility and employment outcomes in a mediated labour market. Human Relations, 58(8), 981-1007.Available at: https://doi.org/10.1177/0018726705058500.

Lillard, R. M., Watts, L. L., Frame, M. C., Hein, M. B., Rigdon, W. D., \& Orsak-Robinson, K. (2012). Initial development and validation of a measure ofadaptive performance. Paper presented at the 27th Annual Conference of the Society for Industrial/Organizational Psychology, San Diego, CA.

Malaysia Education Ministry. (2001). Educational development 2001-2010: Integrated planning for excellence in education. Kuala Lumpur: Ministry of Education Malaysia.

Mogire, J. (2017). Why adaptability and emotional intelligence are indispensable in modern business. Retrieved from: https://www.linkedin.com/pulse/why-adaptability-emotional-intelligence-indispensable-dr-job.

Mohamad, A. M. K., Siti, N. I., Suhaila, M., \& Hasliza, I. (2016). School climate and teacher commitment in Kelantan state government religious school (SABK). Paper presented at the Proceeding of ICECRS.

Mohlman, G. G., Coladarci, T., \& Gage, N. (1982). Comprehension and attitude as predictors of implementation of teacher training. Journal of Teacher Education, 33(1), 31-36.Available at: https://doi.org/10.1177/002248718203300107.

Motowildo, S. J., Borman, W. C., \& Schmit, M. J. (1997). A theory of individual differences in task and contextual performance. Human Performance, 10(2), 71-83.Available at: https://doi.org/10.1207/s15327043hup 1002_1.

Nobile, J. J., \& McCormick, J. (2005). Job satisfaction and occupational stress in catholic primary schools. Paper presented at the Annual Conference of the Australian Association for Research in Education.

O'Connell, D. J., McNeely, E., \& Hall, D. T. (2008). Unpacking personal adaptability at work. Journal of Leadership E Organizational Studies, 14(3), 248-259.Available at: https://doi.org/10.1177/1071791907311005.

Pearlman, K., \& Barney, M. F. (2000). Managing selection in changing organizations: Human resource strategies. San Francisco: Jossey-Bass. 
Ployhart, R. E., \& Bliese, P. D. (2006). Individual adaptability (I-ADAPT) theory: Conceptualizing the antecedents, consequences, and measurement of individual differences in adaptability. In Burke, C.S., Pierce, L.G. and Salas, E. (Eds.), understanding adaptability: A prerequisite for effective performance within complex environments. Advances in human performance and cognitive engineering research (Vol. 6). Oxford: Elsevier.

Poole, M. (2008). Constructing subjective and objective criteria as determinants of perceived career success: A longitudinal study. Journal of Occupational and Organizational Psychology, 66(1), 39-54.

Price Water House Coopers. (2001). Teacher work load study. London: DfES.

Pulakos, E. D., Arad, S., Donovan, M. A., \& Plamondon, K. E. (2000). Adaptability in the workplace: Development of a taxonomy of adaptive performance. Journal of Applied Psychology, 85(4), 612.Available at: https://doi.org/10.1037/002 1-9010.85.4.612.

Riziandy, N., \& Fatimahwati, H. (2013). Influence of personality and competence on adaptive performance of public service psychology officers. Malaysian Journal of Public Service Psychology \& Counseling, 8, 53-69.

Samale, S. L. (2016). Investigating the factor structure of adabtability: A measure of adaptative performance. Master's Thesis Middle Tennessee State University, Murfreesboro, USA.

Schembari. (1994). User design in the creation of human learning systems. Educational Technology Research and Development, 45(3), 5-22.

Trombly, C. E. (2014). School and complexity. An International Journal of Complexity and Education, 11(2), 40-58. 